\title{
Kadar Antosianin, Total Fenol dan Sifat Sensoris Tepung Tape Beras Hitam Berdasarkan Variasi Metode Pengolahan dan Konsentrasi Ragi
}

\author{
Anthocyanin, Total Phenol and Characteristics Sensory of Black Rice Tapai \\ Flour
}

\author{
Marini Firia Dewi, Nurhidajah, Siti Aminah \\ Program Studi S1 Teknologi Pangan \\ Universitas Muhammadiyah Semarang \\ marinifitria@gmail.com
}

\begin{abstract}
Black rice tapai flour is a product that can familiarizing black rice to general public. The purpose of this research was to determine the best formula of black rice tapai flour based on anthosianin content, total phenol and characteristic sensory analization results. The research design used was a Completely Randomized Design (RAL) factorial with two factors, the processing method and yeast concentration. Each factor consists of three levels. Processing methods are steamed, team and boiling black rice using rice cooker and the concentration of yeast is 1\%, 2\% and 3\% so that nine treatment combinations are repeated three times. The results showed that the black rice tapai flour with tim processing method $+2 \%$ yeast concentration is the best formula for tapai flour. Proximate value of black rice tapai flour with tim processing method $+2 \%$ yeast concentration is $11.3 \%$ water content, $7.74 \%$ protein, $4.63 \%$ fat, $19.21 \%$ fiber, $2.51 \%$ ash content and carbohydrate $54.61 \%$.

Keyword: Phenol; Anthocyanin; Tapai flour; Fermentation; Black rice;
\end{abstract}

PENDAHULUAN

Konsumsi beras hitam di Indonesia masih sangat jarang karena kalah populer dengan beras putih. Beras hitam memiliki kelebihan dibandingkan dengan beras putih, diantaranya adalah kaya akan antosianin (Bondre et al., 2012), yang memberikan efek sebagai anti kanker (Hyun dan Chung, 2004) hipoglikemia, dan anti inflamasi (Suda et al., 2003). Antosianin juga memiliki aktivitas antioksidan yang dapat menangkal radikal bebas (Astawan dan Kasih, 2008).
Salah satu diversifikasi produk dari beras hitam yang dapat dikembangkan adalah tepung tape beras hitam. Tape memiliki masa simpan yang relatif pendek, umumnya hanya 3 hari dalam suhu ruang. Menurut Azizah et al., (2012) dan Andriani et al., (2015) tape yang tidak diberi perlakuan pengawetan raginya akan terus aktif melakukan fermentasi hingga batas tertentu, mengubah gula pada tape menjadi alkohol yang kemudian dipecah menjadi asam oleh bakteri Acetobacter. Hal ini membuat tape yang lama 
disimpan memiliki sifat sensoris pada tape akan semakin menyimpang. Salah satu upaya untuk menghentikan fermentasi tersebut sekaligus membuat tape menjadi lebih awet adalah dengan pembuatan tepung tape.

Proses pengolahan beras hitam pada saat pembuatan tape dapat mendegradasi kandungan antosianin dan fenol di dalam beras hitam. Menurut Stanciu et al., (2010) antosianin memiliki kekurangan elektron pada intinya sehingga sangat reaktif terhadap perubahan lingkungan, termasuk perubahan $\mathrm{pH}$ dan suhu. Berdasarkan pendapat tersebut maka proses pemasakan beras, fermentasi, pengeringan serta penepungan pada pembuatan tepung yang melibatkan suhu dan $\mathrm{pH}$ memiliki potensi sebagai faktor pendegradasi antosianin dan fenol dalam beras hitam. Dibutuhkan pengkajian lebih lanjut mengenai dampak berbagai pengolahan serta dampak dari pengeringan dan penepungan terhadap kadar antosianin, alkohol dan fenol pada tepung tape beras hitam.

BAHAN DAN METODE

Bahan
Bahan yang digunakan adalah beras hitam lokal yang diperoleh dari Bantul, Yogyakarta, ragi tape (merk NKL), etanol pa 96\%, KCL, Naasetat, asam asetat, indikator PP, $\mathrm{NaOH}$ 0,1 M, asam oksalat, reagen folin-ciocalteau, $\mathrm{Na}_{2} \mathrm{CO}_{3}$, asam galat (Merck), aquades dan air mineral.

\section{Metode Penelitian}

Rancangan penelitian yang digunakan adalah RAL (Rancangan Acak Lengkap) faktorial dengan 2 faktor, yaitu metode pengolahan beras (kukus, tim dan rice cooker) dan konsentrasi ragi $(1 \%, 2 \%, 3 \%)$. Setiap perlakuan dibagi menjadi 3 kali ulangan sehingga akan diperoleh satuan (unit) percobaan sebanyak 27 unit percobaan

\section{HASIL DAN PEMBAHASAN}

Nilai pH Tepung Tape

Hasil penelitian menunjukkan bahwa nilai $\mathrm{pH}$ terendah yaitu pada tepung tape dengan metode pengolahan tim + ragi $3 \%$. Berdasarkan penelitian dari Nurhidajah, Setiawati dan Nurrahman (2017), beras hitam yang 
dimasak dengan metode tim juga memiliki daya cerna pati yang lebih tinggi $(65,16 \%)$ daripada metode pengolahan lainnya. Daya cerna pati yang tinggi menjadikan beras hitam lebih mudah dihidrolisis oleh enzim pemecah pati sehingga lebih mudah difermentasi. Sehingga lebih cepat menghasilkan asam. Konsentrasi ragi yang semakin tinggi juga mempercepat dan memperbesar kemampuan ragi untuk menguraikan gula menjadi alkohol, sehingga reaksi pemecahan alkohol menjadi asam oleh bakteri pembentuk asam lebih besar pula. Santosa dan Prakosa (2010) menyatakan semakin tinggi konsentrasi ragi maka akan semakin rendah $\mathrm{pH}$ dari tape yang dihasilkan.

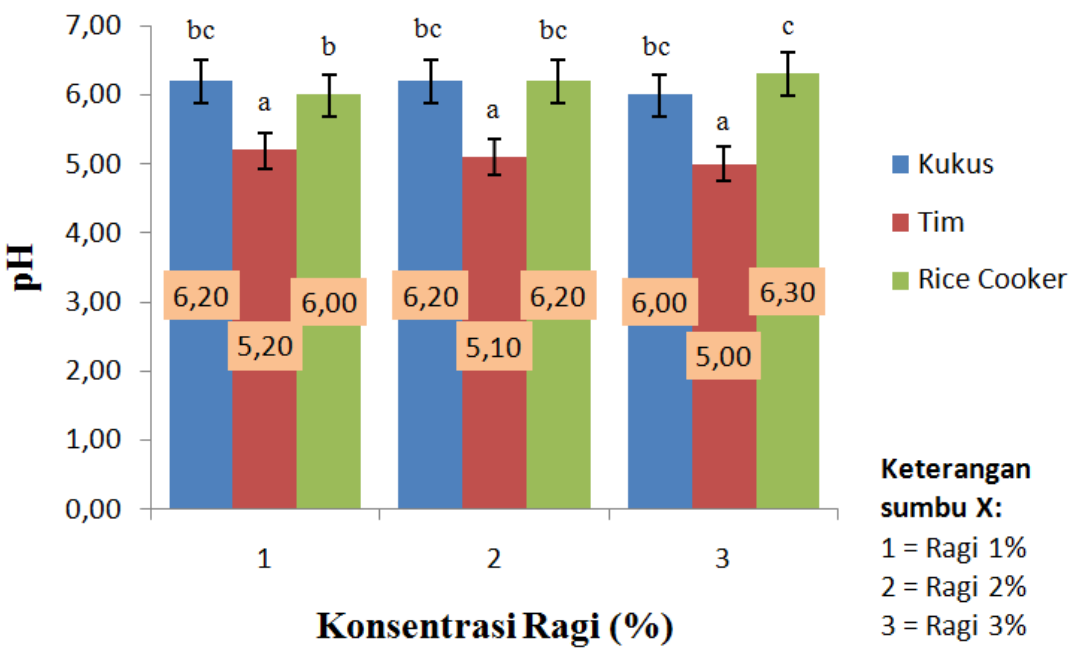

Keterangan: Superskrip yang berbeda menunjukkan hasil yang berbeda nyata $(\mathrm{P}<0.05)$, nilai terendah dimulai dari superskrip a, b, c kemudian $\mathrm{d}$

\section{Gambar 1. Rerata nilai $\mathrm{pH}$ tepung tape beras hitam dengan variasi metode pengolahan dan konsentrasi ragi}

\section{Antosianin}

Hasil penelitian menunjukkan bahwa tidak ada perbedaan pada kadar antosianin terhadap seluruh perlakuan, namun terdapat pengaruh metode pengolahan terhadap kadar antosianin. 


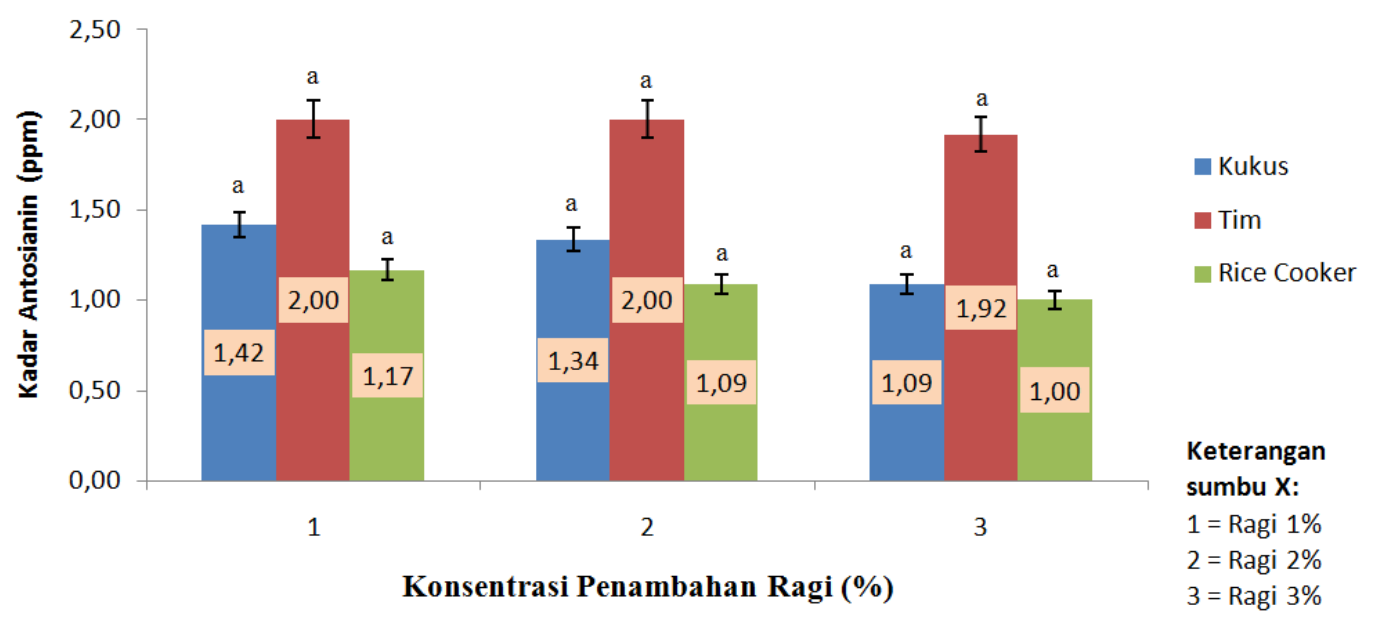

Keterangan: Superskrip yang berbeda menunjukkan hasil yang berbeda nyata $(\mathrm{P}<0.05)$, nilai terendah dimulai dari superskrip a, b, c kemudian $\mathrm{d}$

\section{Gambar 2. Rerata kadar antosianin tepung tape beras hitam dengan} variasi metode pengolahan dan konsentrasi ragi

Pengaruh pengolahan terhadap kadar antosianin dinyatakan pada penelitian dari Suhartatik et al., (2013) bahwa terjadi penurunan kadar antosianin sebanyak lebih dari 50\% pada beras ketan hitam yang dipanaskan pada suhu $>70{ }^{\circ} \mathrm{C}$. Jumlah air yang dibutuhkan serta metode pengolahan yang digunakan untuk penggelatinisasian pati juga dapat menjadi salah satu faktor pendegradasi antosianin karena menurut Chisté, Lopez dan de Faria (2010) dan Xavier et al., (2008) antosianin memiliki sifat larut dalam air.

\section{Nilai derajat putih}

Nilai derajat putih terbaik dalam penelitian ini dipilih berdasarkan tepung dengan nilai derajat putih terendah. Hasil penelitian menunjukkan bahwa tepung tape beras hitam dengan metode pengolahan menggunakan rice cookertragi 1\% menghasilkan tepung dengan derajat putih terendah yaitu 5,48. Kadar antosianin merupakan salah satu hal yang mempengaruhi tingkat intensitas warna tepung tape beras hitam. Antosianin merupakan pigmen alami yang bertanggung jawab terhadap adanya warna merah, biru, ungu hingga kehitaman pada beberapa jenis tumbuhan. Warna tepung tape yang paling gelap dianggap sebagai nilai terbaik karena sifat dari zat antosianin beras hitam yang memiliki pigmen berwarna gelap. Yang et al., (2008) menyatakan bahwa intensitas warna gelap pada beras hitam disebabkan oleh antosianin (sianidin 3- 
glukosidase dan peonidin 3- warna tepung, diindikasikan memiliki glukosidase) pada sel permukaan biji kadar antosianin yang tinggi. sehingga dengan semakin gelapnya

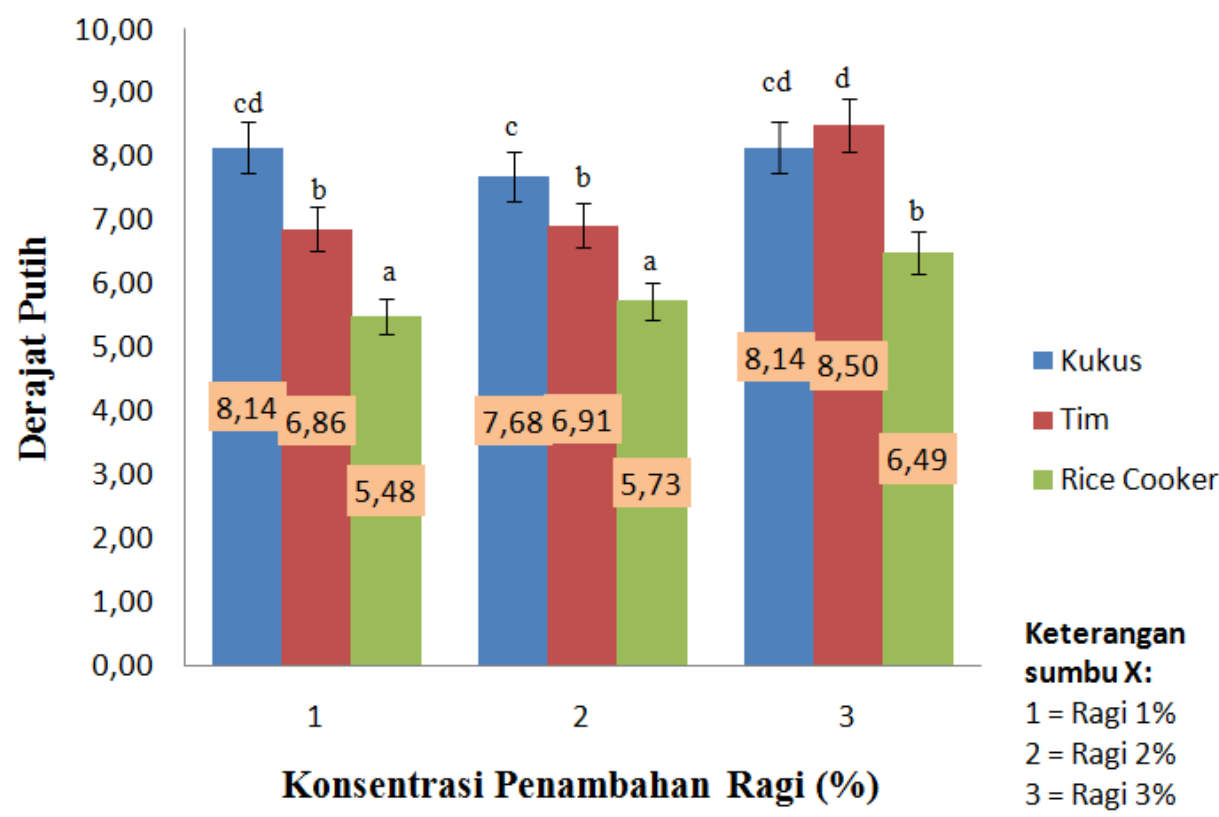

Keterangan: Superskrip yang berbeda menunjukkan hasil yang berbeda nyata $(\mathrm{P}<0.05)$, nilai tertinggi dimulai dari superskrip a, b, c kemudian $\mathrm{d}$

\section{Gambar 3. Rerata nilai derajat putih tepung tape beras hitam dengan variasi metode pengolahan dan konsentrasi ragi}

Pernyataan ini tidak sesuai dengan data pada gambar 2, dimana kadar antosianin dari tepung tape beras hitam seluruh perlakuan tidak memiliki perbedaan yang nyata. Hal ini terjadi karena pada tepung tape beras hitam yang diolah dengan metode pengolahan menggunakan rice cooker mengalami peristiwa karamelisasi sehingga warnanya menjadi lebih gelap. Nasi beras hitam yang diolah dengan menggunakan rice cooker memiliki kadar air yang paling kecil (44,14\%) dibandingkan dengan nasi beras hitam yang diolah dengan metode tim dan kukus (Nurhidajah, Setiawati, Nurrahman, 2017). Pada saat dilakukan pengeringan dengan jumlah waktu yang sama pada masingmasing perlakuan, tape beras hitam yang diolah dengan menggunakan rice cooker menjadi lebih cepat kering daripada tape beras hitam perlakuan lainnya sehingga mengalami karamelisasi lebih banyak daripada tape perlakuan yang lain. Reaksi karamelisasi menghasilkan prekursor pigmen coklat sehingga warna yang 
dihasilkan semakin gelap atau dengan metode pengolahan kecoklatan (Zuliana, Widyastuti dan menggunakan rice cookert ragi $1 \%$ Susanto, 2016).

\section{Total Padatan Terlarut} menghasilkan tepung dengan TPT terbaik yaitu $14.2^{\circ}$ Brix.

Hasil penelitian menunjukkan bahwa tepung tepung tape beras hitam

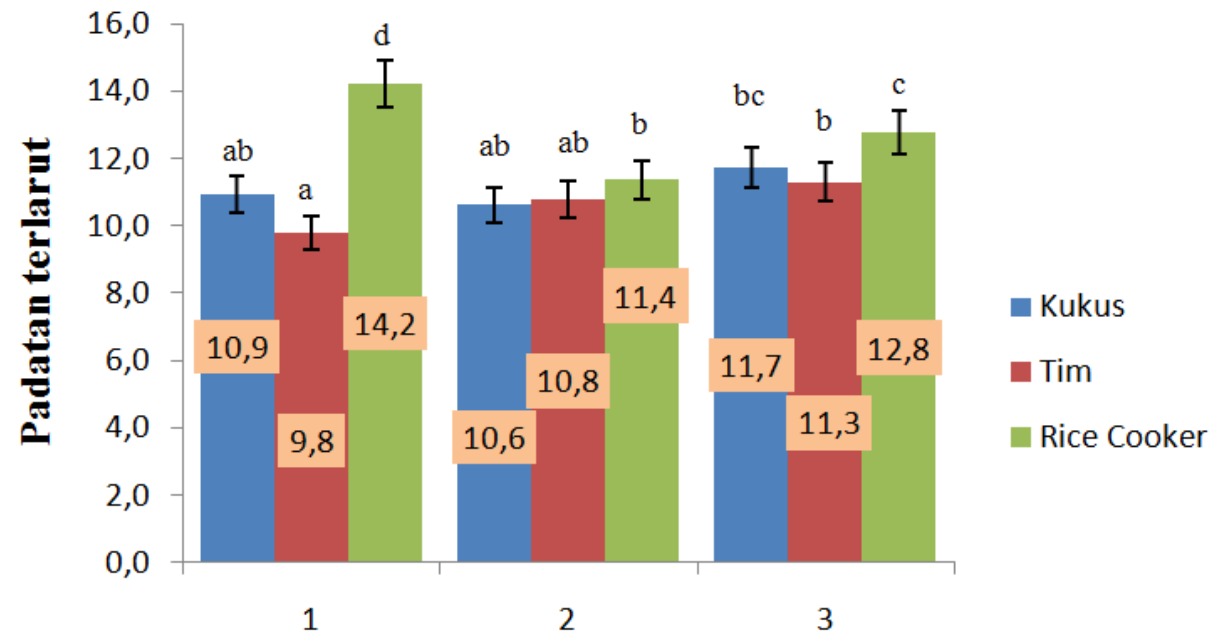

Konsentrasi Ragi (\%)

Keterangan: Superskrip yang berbeda menunjukkan hasil yang berbeda nyata $(\mathrm{P}<0.05)$, nilai terendah dimulai dari superskrip a, b, c kemudian d

Gambar 4. Rerata total padatan terlarut tepung tape beras hitam dengan variasi metode pengolahan dan konsentrasi ragi

Pengolahan beras dengan metode pengolahan menggunakan rice cooker memiliki kadar air yang paling rendah daripada metode pengolahan yang lainnya (Nurhidajah, Setiawati dan Nurrahman, 2017) sehingga total padatan terlarut yang dikandung menjadi tinggi. Nilai TPT terendah terdapat pada metode pengolahan tim+ragi $1 \%$ dengan nilai TPT $\left(9.8^{\circ}\right.$ Brix).
Pengolahan dengan metode tim membuat beras hitam memiliki kadar air yang lebih banyak daripada metode pengolahan lainnya, sehingga membuat total padatan terlarutnya menjadi rendah. Hal ini sesuai dengan penelitian Arindya, Nainggolan dan Lubis (2016) dimana selai kelapa muda dengan jumlah kadar air yang paling rendah memiliki total padatan terlarut yang paling tinggi. Konsentrasi ragi 
yang semakin meningkat menghasilkan total padatan terlarut yang semakin menurun. Semakin banyak jumlah inokulum yang ditambahkan dalam pembuatan tape umbi talas kimpul menyebabkan semakin banyak kandungan pati yang dibongkar oleh enzim amilase menjadi dekstrin menjadi maltosa menjadi gula.
Selanjutnya, gula cepat diubah oleh khamir menjadi alkohol, asam, dan CO2 (Anisa, Bintoro dan Nurwantoro, 2017)

\section{Rendemen}

Hasil penelitian menunjukkan bahwa tidak ada perbedaan pada nilai rendemen terhadap setiap perlakuan.

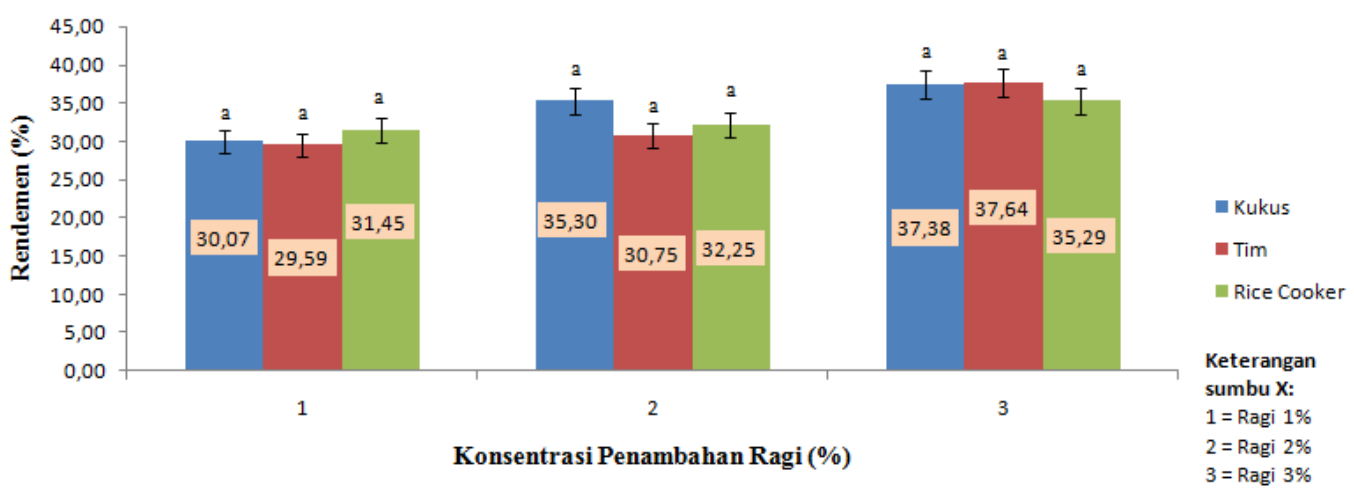

Keterangan: Superskrip yang berbeda menunjukkan hasil yang berbeda nyata $(\mathrm{P}<0.05)$, nilai terendah dimulai dari superskrip a, b, c kemudian $\mathrm{d}$

\section{Gambar 5. Rerata nilai rendemen tepung tape beras hitam dengan variasi metode pengolahan dan konsentrasi ragi}

Pada umumnya fermentasi akan meningkatkan hasil rendemen dari suatu bahan aslinya. Aini, Wijonarko dan Sustriawan (2016) menyatakan bahwa bakteri-bakteri asam laktat dalam fermentasi mampu mendegradasi dinding sel jagung pada tepung jagung terfermentasi, sehingga granula pati keluar dari sel dan mempermudah proses penggilingan. Hal ini diperkuat oleh pernyataan Singh et al., (2009) dimana perendaman butiran jagung pada proses fermentasi mengubah bagian yang keras pada endosperm (borny endosperm) menjadi bagian yang lunak (floury endosperm) dan lebih mudah digiling. Hal tersebut mengakibatkan adanya peningkatan rendemen

\section{Densitas kamba}

Hasil penelitian menunjukkan bahwa tidak ada perbedaan pada nilai densitas kamba terhadap setiap perlakuan. 


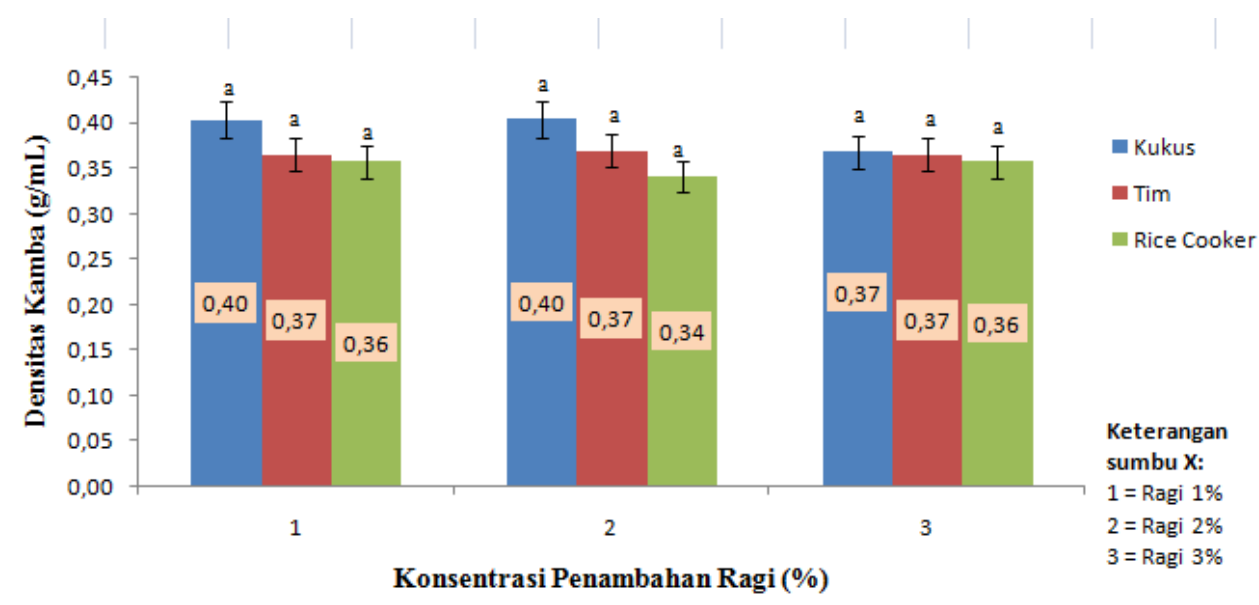

Keterangan: Superskrip yang berbeda menunjukkan hasil yang berbeda nyata $(\mathrm{P}<0.05)$, nilai terendah dimulai dari superskrip a, b, c kemudian d

\section{Gambar 6. Rerata nilai densitas kamba tepung tape beras hitam dengan variasi metode pengolahan dan konsentrasi ragi}

Rerata nilai densitas kamba tepung tape beras hitam berkisar antara $\quad 0,36 \quad-\quad 0,4 \quad \mathrm{~g} / \mathrm{mL}$. Wirarkartakusumah, Kamarudin dan Syarif (1992) menyatakan bahwa nilai densitas kamba produk bubuk seperti tepung yang baik berkisar antara 0.30 $0.80 \mathrm{~g} / \mathrm{mL}$. Hal ini menunjukkan bahwa tepung tape beras hitam telah dapat dinyatakan kamba. Suatu bahan dapat dinyatakan kamba apabila nilai densitas kambanya kecil, yang artinya untuk volume yang besar berat bahan ringan (Anita, 2009).

\section{Daya serap air}

Hasil penelitian menunjukkan bahwa tepung tepung tape beras hitam dengan metode pengolahan kukus+ragi 2\% menghasilkan tepung dengan daya serap terbaik yaitu 1,57 $\mathrm{ml} / \mathrm{g}$. Beras yang dimasak dengan metode kukus memiliki daya cerna yang paling tinggi diantara perlakuan lain, sehingga lebih cepat terfermentasi oleh mikroba. Kinanti, Amanto dan Atmaka (2014) menyataka bahwa semakin tinggi konsentrasi asam laktat maka semakin tinggi juga swelling power yang terkandung dalam tepung sorghum termodifikasi. Hal ini disebabkan karena asam dapat menyebabkan ikatan hidrogen dalam pati melemah sehingga air mudah masuk kedalam granula pati. Proses tersebut membuat granula pati lebih mengembang. Swelling power dan kelarutan terjadi karena adanya ikatan non-kovalen antara molekul-molekul pati. Bila pati dimasukkan ke dalam air dingin, granula pati akan menyerap air 
dan membengkak. Daya serap air berpengaruh terhadap kadar amilosa dan amilopektin dalam tepung. Makin tinggi amilosanya maka makin baik daya serapnya Luna et al., (2015).

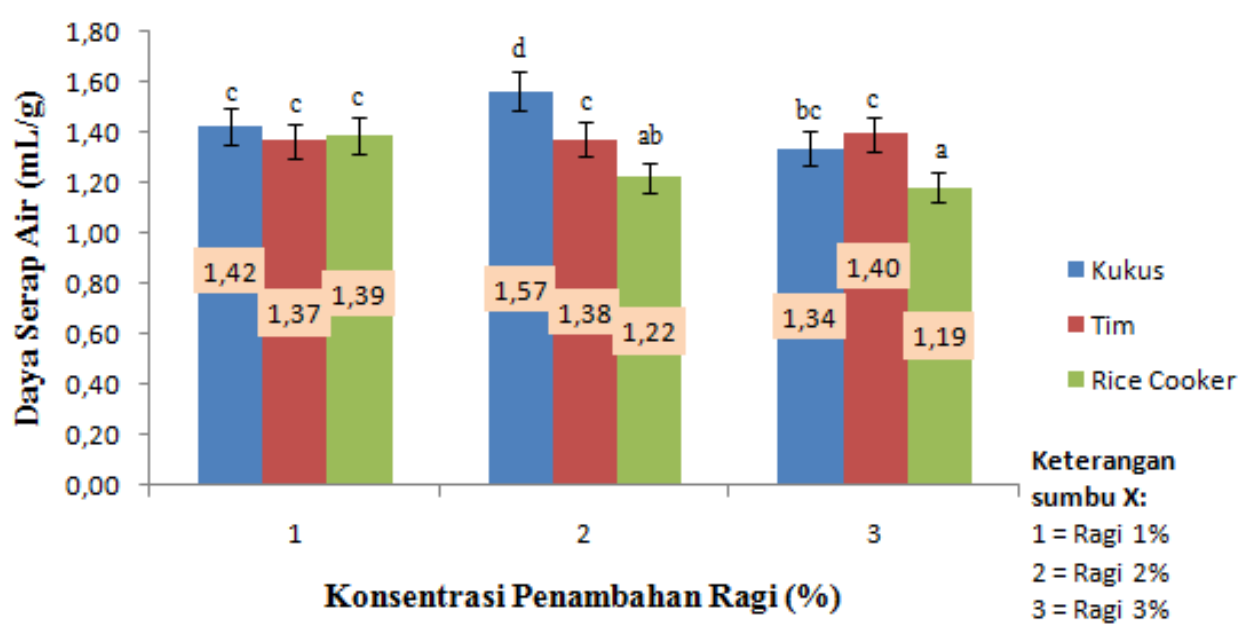

Keterangan: Superskrip yang berbeda menunjukkan hasil yang berbeda nyata(P $<0.05)$, nilai terendah dimulai dari superskrip a, b, c kemudian d

\section{Gambar 7 . Rerata nilai daya serap air tepung tape beras hitam dengan variasi metode pengolahan dan konsentrasi ragi}

Uji alkohol

Kadar alkohol dalam tepung tape beras hitam sulit terdeteksi dalam pengujian karena kadarnya yang sangat rendah, sehingga dapat dinyatakan bahwa kadar alkohol dalam tepung tape telah sangat rendah. Hal ini dapat terjadi karena sifat alkohol menguap pada suhu $78^{\circ} \mathrm{C}$, sehingga akan banyak menguap pada saat pengeringan tape dengan cabinet drying dalam waktu yang lama. Kadar alkohol dalam tape beras hitam dengan variasi metode pengolahan dan konsentrasi ragi disajikan pada Tabel 1 sebagai berikut

Tabel 1. Kadar alkohol dalam tape beras hitam (\%)

\begin{tabular}{cccc}
\hline \multirow{2}{*}{ Jumlah ragi } & \multicolumn{3}{c}{ Perlakuan } \\
\cline { 2 - 4 } & Kukus & Tim & Rice cooker \\
\hline $1 \%$ & 2.52 & 3.44 & 3.18 \\
$2 \%$ & 2.64 & 3.65 & 3.16 \\
$3 \%$ & 2.98 & 3.93 & 3.28 \\
\hline
\end{tabular}

Pada Tabel 1 dapat ditarik kesimpulan bahwa kadar alkohol akan cenderung semakin meningkat dengan bertambahnya jumlah penambahan ragi. Widiyaningrum menyatakan bahwa tinggi rendahnya 
kadar alkohol yang dihasilkan setelah proses fermentasi berhubungan dengan jumlah khamir yang ada, terjadinya pertumbuhan khamir berhubungan dengan aktifitas enzim amilase yang mengubah pati menjadi maltosa, dan dengan enzim maltase, maltosa akan dihidrolisis menjadi glukosa. Tape beras hitam dengan metode pengolahan tim memilki kadar alkohol yang paling tinggi diantara metode pengolahan lain. Berdasarkan penelitian dari Nurhidajah, Setiawati dan Nurrahman (2017) nilai daya cerna beras hitam yang diolah dengan metode tim memiliki nilai daya cerna yang paling tinggi diantara metode pengolahan yang lain. Hal ini mempermudah kerja mikroba pada ragi sehingga mempercepat proses fermentasi. Jumlah konsentrasi ragi juga berpengaruh dalam pembentukan alkohol karena terlihat pada Tabel 1 bahwa semakin banyak konsentrasi ragi yang ditambahkan maka jumlah kadar alkoholnya juga semakin besar.

\section{Total Fenol}

Hasil dari pengujian total fenol tape beras hitam maupun tepung tape beras hitam adalah negatif, yang berarti bahwa tidak terdeteksi adanya zat fenol baik pada tepung tape beras hitam maupun pada tape beras hitam.
Hal ini sejalan dengan penelitian dari Nurhidajah, Setiawati dan Nurrahman (2017) dimana total fenol dari nasi beras hitam yang diolah dengan metode kukus, tim dan menggunakan rice cooker terdeteksi dalam jumlah yang sangat sedikit yaitu masing-masing sebesar 0,026, 0,058 dan 0,059 \%. Pada proses pembuatan tepung tape beras hitam kadar dari fenol akan semakin berkurang akibat terpapar oleh suhu panas pada saat proses pengolahan beras dan pengeringan. Reblova (2012) menyatakan bahwa penurunan kadar fenolik disebabkan karena degradasi antosianin akibat panas.

\section{Sifat sensoris}

a. Warna

Gambar 8 menunjukkan diagram nilai warna tepung tape beras hitam berkisar antara 2,40 (mendekati suka) sampai 3,40 (mendekati sangat suka) dengan kriteria sangat suka sampai dengan sangat tidak suka. Warna tepung tape beras hitam yang paling disukai panelis terdapat pada metode pengolahan tim+ragi 3\% dengan nilai 3,40 dengan kategori agak hitam, namun tidak berbeda nyata dengan perlakuan metode pengolahan tim+ konsentrasi ragi lainnya dan metode pengolahan dengan 
menggunakan rice cookert ragi 3\%.

Penulis kurang menyukai tepung tape yang berwarna hitam namun paling menyukai warna yang agak hitam diduga disebabkan oleh panelis masih kurang familiar dengan tepung yang berwarna hitam karena sifat tepung yang umumnya berwarna putih.

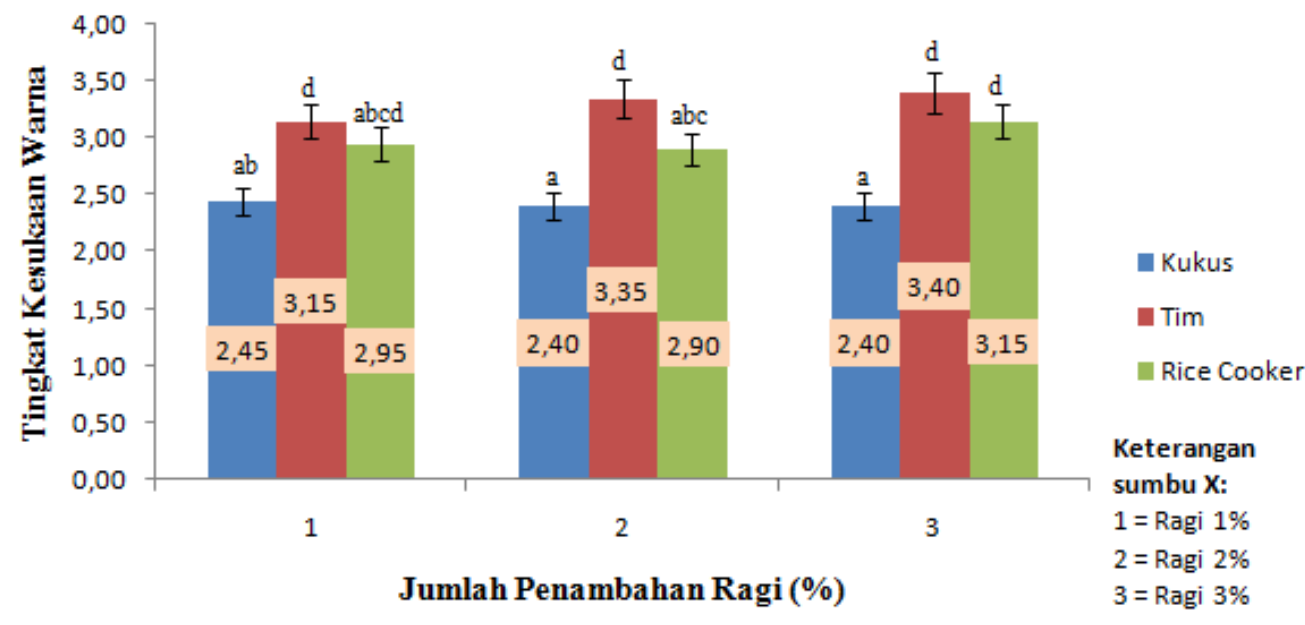

Keterangan: Superskrip yang berbeda menunjukkan hasil yang berbeda nyata $(\mathrm{P}<0.05)$, nilai terendah dimulai dari superskrip a, b, c kemudian $\mathrm{d}$

\section{Gambar 8. Rerata nilai hedonik warna tepung tape beras hitam dengan variasi metode pengolahan dan konsentrasi ragi}

\section{b. Aroma}

Gambar 9 menunjukkan diagram nilai aroma tepung tape beras hitam berkisar antara 2,50 (mendekati suka) sampai 3,40 (mendekati sangat suka) dengan kriteria sangat suka sampai dengan sangat tidak suka. Aroma tepung tape beras hitam yang paling disukai panelis terdapat pada perlakuan kukus+ragi 1\% dengan nilai 3,40. Hal ini diduga karena tepung tape dengan metode pengolahan kuku + ragi $1 \%$ masih memiliki aroma khas tape yang lebih manis. Rendahnya konsentrasi ragi dan $\mathrm{pH}$ yang basa diduga membuat aroma tape yang timbul menjadi lebih manis dan tidak asam. Rerata nilai hedonik aroma terendah terdapat pada tepung dengan metode pengolahan menggunakan rice cooker+ ragi 1\% dengan nilai 2,30. 


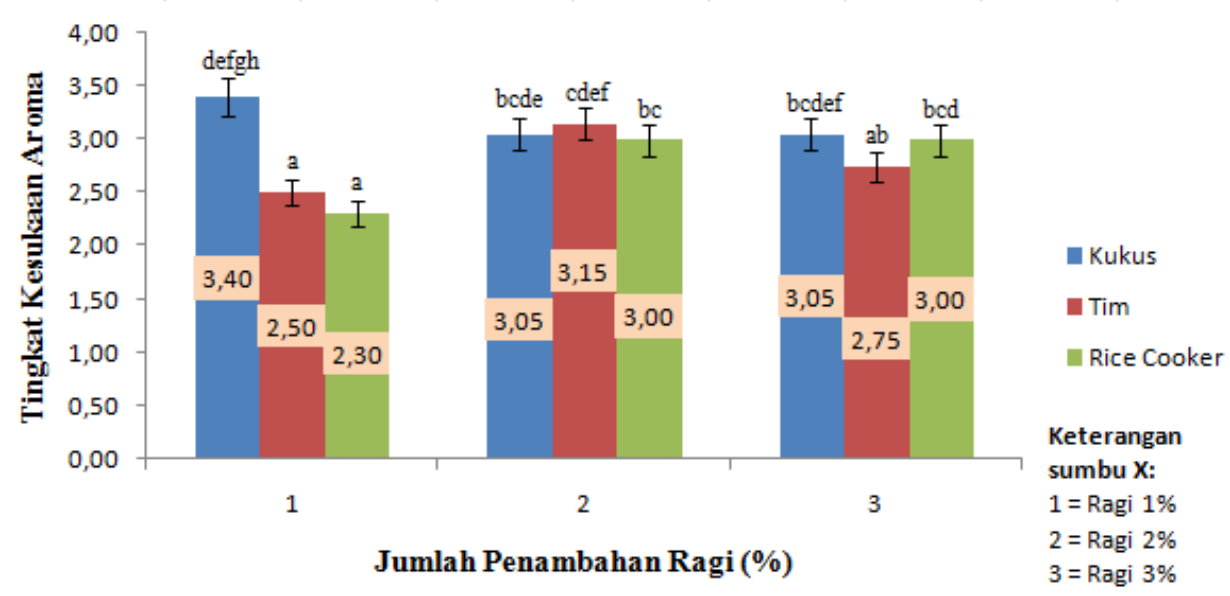

Keterangan: Superskrip yang berbeda menunjukkan hasil yang berbeda nyata(P <0.05), nilai terendah dimulai dari superskrip a, b, c kemudian d

\section{Gambar 9. Rerata nilai hedonik aroma tepung tape beras hitam dengan variasi metode pengolahan dan konsentrasi ragi}

\section{c. Tekstur}

Gambar 10 menunjukkan

diagram nilai tekstur tepung tape beras hitam berkisar antara 2,60 (mendekati suka) sampai 3,65 (mendekati sangat suka) dengan kriteria sangat suka sampai dengan sangat tidak suka.
Tekstur tepung tape beras hitam yang paling disukai panelis terdapat pada perlakuan kukus+ragi 3\% dengan nilai $(3,65)$ dan tim+ragi 3\% dengan nilai $(3,05)$.

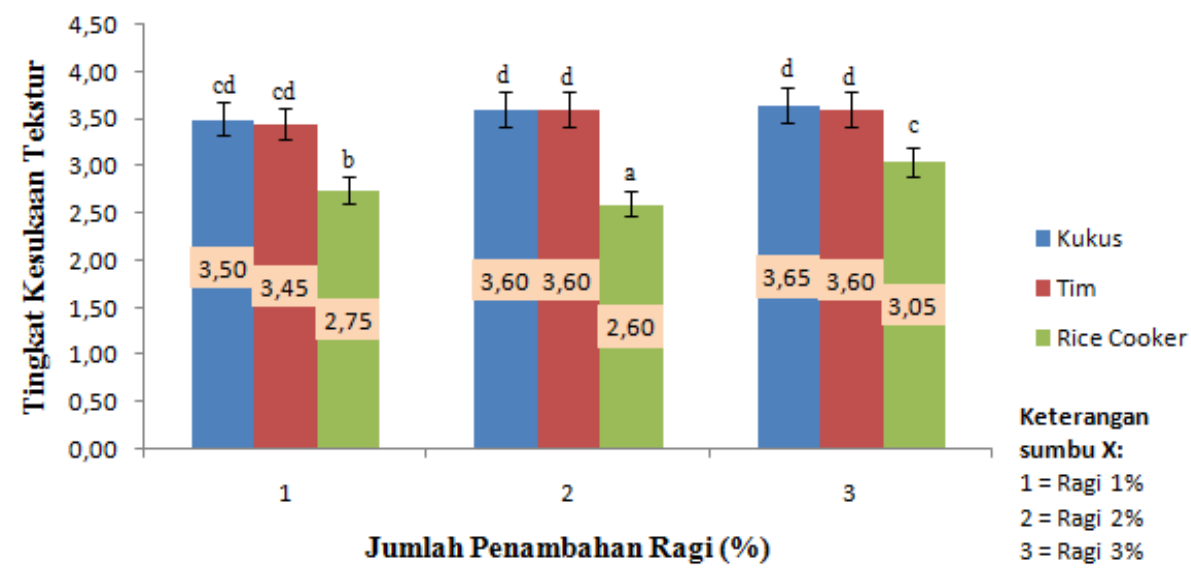

Keterangan: Superskrip yang berbeda menunjukkan hasil yang berbeda nyata $(\mathrm{P}<0.05)$, nilai terendah dimulai dari superskrip a, b, c kemudian $\mathrm{d}$

Gambar 10. Rerata nilai hedonik tekstur tepung tape beras hitam dengan variasi metode pengolahan dan konsentrasi ragi 
Rerata nilai hedonik tekstur terendah terdapat pada tepung dengan metode pengolahan menggunakan rice cooker+ragi 2\% dengan nilai $(2,60)$ dan metode pengolahan menggunakan rice cooker+ragi $1 \%$ dengan nilai $(2,75)$. hal ini dikarenakan kadar air dari nasi beras hitam yang diolah dengan menggunakan rice cooker memiliki kadar air yang lebih rendah daripada nasi beras hitam yang diolah dengan metode tim dan kukus, sehingga lama pemanasannya akan menjadi lebih lama daripada tape perlakuan yang lain pada saat dikeringkan dengan jumlah waktu yang sama sehingga membuat gula yang terkandung dalam tape terkaramelisasi dan teksturnya berubah menjadi lebih lengket.
Hasil perhitungan citarasa dari tepung tape beras hitam dengan variasi metode pengolahan dan konsentrasi ragi disajikan pada Gambar 21. Gambar 21 menunjukkan bahwa urutan nilai rerata kesukaan panelis terhadap tepung tape secara keseluruhan, tepung tape dengan metode pengolahan tim+ragi $2 \%$ memiliki nilai citarasa tertinggi, sementara tepung tape metode pengolahan menggunakan rice cooker+ragi 1\% memiliki nilai citarasa terendah. Tepung tape beras hitam dengan metode pengolahan tim+ penambahan konsentrasi ragi $2 \%$ merupakan tepung yang paling disukai oleh panelis karena memiliki nilai ratarata kesukaan overall (warna, aroma, tekstur) paling tinggi.

d. Citarasa

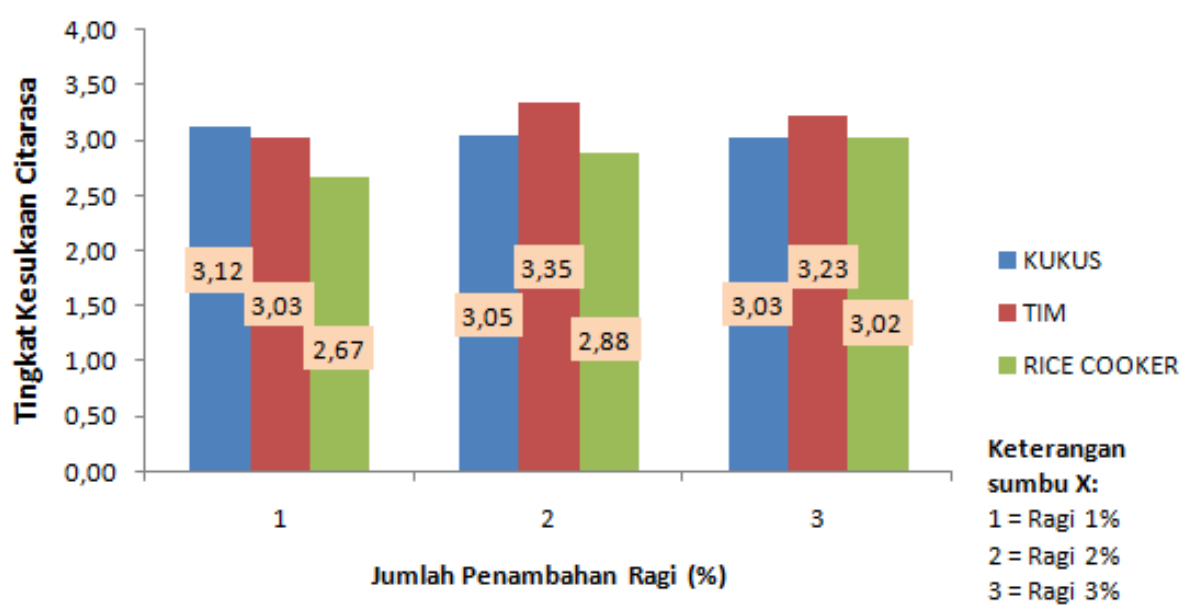

Gambar 11. Rerata nilai citarasa tepung tape beras hitam dengan variasi metode pengolahan dan konsentrasi ragi

\section{Kesimpulan}


Berdasarkan penelitian ini dapat disimpulkan bahwa perlakuan metode pengolahan dan konsentrasi ragi sangat berpengaruh nyata Arindya, A., Nainggolan, R.J., Lubis, L.M. terhadap $\mathrm{pH}$, derajat putih, total padatan terlarut, daya serap air, hedonik warna, aroma serta tekstur. Hasil analisis kadar antosianin, fenol dan sifat sensori tepung tape beras hitam terbaik dihasilkan dari metode pengolahan tim dengan konsentrasi ragi $2 \%$, dengan karakteristik proksimat kadar air $11.3 \%$, protein $41.83 \%$, lemak $4.63 \%$, serat $19.21 \%$, kadar abu 2.51\% dan karbohidratBondre, S., Patil, P., Amaraja, K. and Pillai, $20.52 \%$

\section{DAFTAR PUSTAKA}

Aini, N., Wijonarko, G., Sustriawan, B. 2016, Sifat fisik, kimia dan fungsional tepung jagung yang diproses melalui fermentasi. Jurnal Agritech 36(2): 160169.

Andriani, W., Darmawati dan Wulandari, S. 2015. Kajian lama fermentasi terhadap kadar alkohol tape ketan hitam (oryza sativa glutinosa) sebagai pengembangan lembar kerja siswa pada konsep bioteknologi konvensional kelas xii sma. JOM Fakultas Keguruan dan Ilmu Pendidikan Universitas Riau 2 (2): 1-12.

Anisa, F.A., Bintoro, V.P., Nurwantoro. 2017. Mutu kimia dan organoleptik tape hasil fermentasi umbi talas kimpul (xanthosoma sagittifolium) dengan berbagai konsentrasi ragi. Jurnal Aplikasi Teknologi Pangan 6 (1): 4347.

Anita, Sri. 2009. Studi sifat fisiko-kimia, sifatfungsional karbohidrat, dan aktivitasantioksidan tepung kecambah kacang komak (lablab purpureus (1.) Sweet). (Skripsi). Fakultas Teknologi Pertanian. Institut Pertanian Bogor. Bogor. 2016. Pengaruh konsentrasi karagenan terhadap mutu selai kelapa muda lembaran selama penyimpanan. Jurnal Rekayasa Pangan dan Pertanian 4(1): 72-77.

Astawan, M. dan Kasih, A.L. 2008. Khasiat Warna-Warni Makanan. Gramedia Pustaka Utama, Jakarta.

Azizah, N., Al-Baarri, A. N. dan Mulyani, S. 2012. Pengaruh lama fermentasi terhadap kadar alkohol, ph dan produksi gas pada proses fermentasi bioetanol dari whey dengan subtitusi kulit nanas. Jurnal Aplikasi Teknologi Pangan 1 (2): 72-77.

M.M. 2012. Study on isolation and purification of anthocyanins and its application as $\mathrm{ph}$ indicator. International Journal of Advanced Biotechnology And Research, 3 (3): 698-702.

Chisté, R.C., Lopes, A.S., de Faria, L.J.G. 2010. Thermal and light degradation kinetics of anthocyanin extracts from mangosteen peel (Garcinia mangostana L.) Int J Food Sci Tech 45: 1902-1908. DOI: 10. 1111/j.13652621.2010.0235.x.

Hyun, J.W. and Chung, H.S. 2004, Cyanidin and malvidin from oryza sativa cv. Heungjinjubyeo mediate cytotoxicity agaist human monocytic leucimia cell by arrest of $\mathrm{g}(2) / \mathrm{m}$ phase and induction of apoptosis. J.Agric. Food chem., 52(8): 2213-2217.

Kinanti, P.S.K., Amanto, B.S., Atmaka, W. 2014. Kajian karakteristik fisik dan kimia tepung sorghum (sorghum bicolor I) varietas mandau termodifikasi yang dihasilkan dengan variasi konsentrasi dan lama perendaman asam laktat. 
Jurnal Teknosains Pangan 3(1): 135144.

Luna, P., Herawati, H., Widowati, S. Prianto, A.B. 2015. Pengaruh kandungan amilosa terhadap karakteristik fisik dan organoleptik nasi instan. Jurnal Penelitian pasca Panen PertanianSuhartatik, N., Karyantina, M., Mustofa, A., 12(1).

Nurhidajah, Setiawati, Y.N. dan Nurrahman. 2017. Beras hitam sebagai inhibitor aterosklerosis pada tikus dengan diet aterogenik.

Universitas

Muhammadiyah, Semarang.

Reblova, Z. 2012. Effect of

temperature on the antioxidant activity of phenolic acids. Czech. J. Food Sci., 30 (2), 171-177

Santosa, A. dan Prakosa, C. 2010.

Karakteristik Tape Buah Sukun HasilXavier, M.F., Lopes, T.J., Quadri, M.G.N., Fermentasi Penggunaan Konsentrasi Ragi Yang Berbeda. Magistra 22(73).

Singh, N., Bedi, R., Garg, R., Garg, M., and Singh, J. 2009. Physico-chemical, thermal and pasting properties of fractions obtained during three successive reduction milling ofYang, D.S., Lee, K.S., Jeong, O.Y., Kim, K.J., different corn types. Food Chemistry 113(1): 71-77.

Stanciu, G., Lupsor, S., Sava, C. and Zagan, S. 2010. Spectrophotometric study on stability of anthocyanins extracts fromZuliana, C., Widyastuti, E., dan Susanto, W.H. black grapes skins. J Ovidius University Annals of Chemistry 21(1): 101-104.

Suda, I., Oki, T., Masuda, M., Kobayashi, M., Nishiba, Y. dan Furuta, S. 2003.
Physiological functionality of purple fleshed sweet potatoes containing anthocyanins and their utilization in foods. Japan agricultural research quarterly 37(3): 167-173. Rahayu, E.S. 2013. Stabilitas ekstrak antosianin beras ketan (oryza sativa var. Glutinosa) hitam selama proses pemanasan dan penyimpanan. Agritech 33(4): 384-390.

Widiyaningrum, C. 2009. Pengaruh Bahan Penutup Terhadap Kadar Alkohol pada Proses Bioetanol Ubi Kayu Bahan Bakar Masa Depan. PT Agromedia Pustaka, Jakarta. and Quadri, M.B. 2008. Extraction of red cabbage anthocyanins: optimization of the operation conditions of the column process. brazz.arch biol. Technol 51(1): 143152.

Kays, S.J. 2008. Characterization of volatile aroma compounds in cooked black rice. Journal of Agricultural and Food Chemistry 56(1): 235-240. 2016. Pembuatan gula semut kelapa (kajian $\mathrm{pH}$ gula kelapa dan konsentrasi natrium bikarbonat). J. Pangan dan Agroindustri 4(1): 109-119 